\title{
Evaluation of the antibacterial activity of skin mucus of three carp species
}

\author{
Sunil Kumari $\cdot$ Anil Kumar Tyor • Anita Bhatnagar [
}

Received: 29 December 2018/ Accepted: 1 July 2019/Published online: 6 July 2019

(C) The Author(s) 2019

\begin{abstract}
Studies were conducted to evaluate the antimicrobial potency of skin mucus collected from three carp species; Hypophthalmichthys nobilis, Ctenopharyngodon idella, and Cyprinus carpio (exotic to India) against certain human and fish pathogenic bacterial strains viz. Klebsiella pneumoniae, Pseudomonas aeruginosa, Escherichia coli, Staphylococcus epidermidis, Staphylococcus aureus, Bacillus cereus, and Aeromonas hydrophila. The antimicrobial activities were measured in terms of zone of inhibition (ZOI) in mm and compared with two antibiotics (amikacin and chloramphenicol). All selected fish species were also challenged with A. hydrophila through water to check, if there is any change in mucus secretion or its antibacterial effects. Studies have shown that after challenge with A. hydrophila, an increase in mucus secretion was observed in all the three species of carps. Skin mucus extracts (crude and aqueous) obtained from healthy and challenged fish species exhibited strong antibacterial activity against all the investigated microbial strains. Variations in antibacterial effect have been observed among same fish (in healthy and challenged) and amidst different carp species against same and different bacterial strains. In general, crude mucus of all the fish species showed higher bactericidal action than its aqueous extracts and antibiotic chloramphenicol. Hence, these results have clearly revealed that the mucus obtained from fish skin shows antibacterial activity which may play an important role in fish protection against pathogens and thus there appears to be a possibility of using mucus obtained from the skin of carps as an alternative to antibiotics in animals and possibly also in human health related problems.
\end{abstract}

Keywords Fish $\cdot$ Microorganisms $\cdot$ Skin mucus $\cdot$ Zone of inhibition $\cdot$ Antibacterial activity

\section{Introduction}

Fishes represent the largest class of aquatic cold blooded vertebrates and form the minor and major links between food webs of the aquatic ecosystems which harbor a wide range of pathogenic organisms (Ellis 2001).

Infectious diseases caused by bacteria, viruses and other parasitic organisms are primary concern in aquaculture. Effective management of infectious diseases is one of the most critical elements for successful aquaculture (Cooper and Shlaes 2011). The maintenance of large numbers of fish in a small area provides an environment conducive for the development and spread of infectious diseases. In crowded, relatively unnatural environment, fish are stressed and more susceptible to diseases. Moreover, the water environment, and limited water flow, facilitates the spread of pathogens within crowded populations. According to Dash

S. Kumari · A. K. Tyor · A. Bhatnagar $(\bowtie)$

Department of Zoology, Kurukshetra University, Kurukshetra, Haryana 136119, India

e-mail: anitabhatnagar@gmail.com 
et al. (2018) problems of infectious diseases become more acute when fish are grown in high densities in intensive aquaculture. However, aquatic organisms like fishes are endowed with innate immunological subsystem that provides the first line of defense in the form of epidermal mucus containing immune components, secreted by goblet cells (Pearson and Brownlee 2005) that provide the primary defense against different pathogenic microbes and act as a barrier between fish and its immediate niche. This perhaps may be a major contributing factor for their successful survival. According to Lirio et al. (2018) lying at the interface between fish and the aqueous environment, fish skin mucus is the key component of fish's innate immune system and it combats pathogens from the very moment of their first contact. Nagashima et al. (2003) demonstrated that fish skin mucus is constantly secreted and replaced, hence the microbes or other particles entrapped in it are washed off, which helps to prevent the stable colonization of potential infectious microorganisms. Pearson and Brownlee (2005) reported that mucus is a slimy secretion, consisting of mucins and a combination of other substances such as inorganic salts, immunoglobulin, proteins and lipids suspended in water giving it characteristic lubricating properties which help in choking of pathogens. Al-Arifa et al. (2013) demonstrated that skin mucus is a complex fluid and its composition varies throughout the epithelial surface of fish. According to Ellis (2001), composition and rate of mucus secretion varies from species to species and has been observed to change in response to microbial exposure or to environmental fluctuations such as hyperosmolarity and $\mathrm{pH}$, etc. Further, many authors (Alvarez-Pellitero 2008; Guardiola et al. 2014; Hedmon 2018) have demonstrated that mucus also acts as a storehouse for innate immune components such as lectins, pentraxines, lysozymes, proteolytic enzymes, alkaline phosphatase, C-reactive protein, complement, and antimicrobial peptides (AMPs) as well as immunoglobulins which provide antibacterial strength to fish skin mucus. In recent years, many investigators have investigated the antibacterial properties of skin mucus from many a fish species against several human and fish pathogenic microbes (Wei et al. 2010; Bragadeeswaran and Thangaraj 2011; Vennila et al. 2011; Fuochi et al. 2017; Reverter et al. 2018) which supported the hypothesis that the epidermal mucus plays a protective role and should be effective against fish and human pathogenic bacteria as well. However, comprehensive information on the antimicrobial activity of epidermal mucus in fresh water fishes of different habits and habitats is still lacking. Each species has its own habit and habitat, living in different kinds of watery environment, consumes different types of food, which may influence the amount of mucus secretion and its components within the species or between the species and can be helpful in providing variety of immune response and components. Therefore, the objectives of the present studies were: (1) to analyze the antibacterial effect of skin mucus of three fresh water carp species viz. Hypophthalmichthys nobilis, Ctenopharyngodon idella, and Cyprinus carpio which are exotic to India and cultured in polyculture with indigenous carps, (2) to investigate, if there is any change in mucus secretion and its antibacterial effect after bacterial challenge, and (3) to analyze healthy and challenged fish skin mucus of all three fish species to evaluate the MICs against all selected microbial strain for studies.

\section{Materials and methods}

Fish collection and maintenance

Growing live specimen of the three carps species (H. nobilis, C. idella, and C. carpio) were obtained from the fish farms situated in and around the vicinity of Kurukshetra, Haryana [see Table 1 for average length (total

Table 1 Average total length, average weight, and appearance of mucus of experimental fishes

\begin{tabular}{|c|c|c|c|}
\hline Fish & Average length $(\mathrm{cm})$ & Average weight $(\mathrm{g})$ & Viscosity and appearance of mucus (visual observation) \\
\hline H. nobilis & $28.60 \pm 1.15$ & $562.00 \pm 56.18$ & $\begin{array}{l}\text { Less viscous (visually observed) and very low in } \\
\text { amount than } C \text {. idella and } C \text {. carpio, it become more } \\
\text { watery in winters }\end{array}$ \\
\hline C. idella & $30.64 \pm 0.59$ & $507.80 \pm 47.58$ & Frothy in nature \\
\hline C. carpio & $28.87 \pm 0.66$ & $449.86 \pm 38.26$ & $\begin{array}{l}\text { Highly viscous/sticky (when compared with other two } \\
\text { selected fish species) with yellowish tinge, secretes } \\
\text { almost equal amount of mucus during summers and } \\
\text { winters }\end{array}$ \\
\hline
\end{tabular}


length) and average weight of fishes used in the experiment] and transported to the Fish and Fisheries laboratory, Department of Zoology, Kurukshetra University, Kurukshetra. Fish were maintained in fiber-glass reinforced plastic (FRP) tank/s (capacity 1000 1). To maintain the hygiene condition and water quality half of the water in the tank was changed on alternate days. Health of fish was observed daily and dead fish if any or fish with any lesions were removed from tank. All the fishes were fed daily with formulated feed (pellets formed by mixture of rice bran, groundnut oil cakes, wheat flour, and mineral mixture) at $4 \%$ of their body weight during the acclimation period.

Mucus collection

After acclimation for 7 days, fishes were starved for $24 \mathrm{~h}$ and washed with $4 \%$ of potassium permanganate $\left(\mathrm{KMnO}_{4}\right)$ solution before mucus collection. No chemical or anesthesia was given to the fishes for collection of skin mucus. Mucus was taken from 15 representatives each of species. Mucus was carefully scraped from dorsal surface of body by moving a sterile plastic spatula in anterio-posterior direction, from head to tail, and mucus was collected at regular intervals (10 attempts in 1 day). Collection of mucus from the ventral area was avoided to eliminate intestinal and urinogenital contamination (Chong et al. 2005). The mucus samples were frozen in ice at $0{ }^{\circ} \mathrm{C}$ to avoid bacterial growth.

Test microorganisms

All microbial strains studied (six human pathogen including three Gram-negative bacterial strains Escherichia coli, Klebsiella pneumoniae, Pseudomonas aeruginosa, and three Gram-positive bacterial strains Staphylococcus aureus, Staphylococcus epidermidis, Bacillus cereus and one fish pathogenic Gram-negative bacterial strain Aeromonas hydrophila were procured from Institute of Microbial Technology (IMTECH), Chandigarh, India.

All the bacterial strains were cultured as per the microbiological safety protocols and conditions by Eder et al. (2009). Each microbial strain was grown at $37{ }^{\circ} \mathrm{C}$ in nutrient broth $(0.5 \%$ peptone, $0.5 \% \mathrm{NaCl}, 0.3 \%$ beef extract, distilled water, $\mathrm{pH} 6.8$ at $28{ }^{\circ} \mathrm{C}$ ). Then, colony forming units (CFU) of each bacterial strain were calculated by CFU method (Barbosa et al. 1995).

Challenge experiment

10 fishes of each species were challenged with fish pathogenic bacteria (Austin et al. 1995) A. hydrophila cultured and maintained in the agar media. Fishes were immersed in a suspension of A. hydrophila approximately $10^{7} \mathrm{CFU} \mathrm{ml} \mathrm{m}^{-1}$. Mucus was collected on third day and then on seventh day. No significant change was observed in the volume of mucus secretion by challenged fish when compared with healthy fish. Therefore, second immersion of approximately $10^{9} \mathrm{CFU} \mathrm{ml}{ }^{-1}$ was done for 15 days and mucus was collected after an interval of 1 week by skin scrapping method.

Mucus extracts preparations

Crude mucus extracts of both selected healthy and challenged fish species were prepared by centrifuging raw fish skin mucus at 5000 revolutions per minute (RPM) for $5 \mathrm{~min}$. For aqueous mucus extracts, collected raw mucus was thoroughly mixed with equal quantity of sterilized physiological saline $(0.85 \% \mathrm{NaCl})$ and centrifuged at 5000 RPM for 5 min (Kuppulakshmi et al. 2008). Both mucus extracts (crude and aqueous) were stored at $0{ }^{\circ} \mathrm{C}$ for further studies.

\section{Protein estimation}

Amount of protein in fish mucus of different species was determined using Lowry et al. (1951). 
Agar well diffusion assay

The antibacterial effect of healthy fish mucus (HFM) and challenged fish mucus (CFM) extracts of all experimental fishes on the selected bacterial strains were assayed by Agar well diffusion method (Valgas et al. 2007). Petri plates containing $15 \mathrm{ml}$ nutrient agar medium were seeded with 24-h culture of approximately $10^{7}$ CFU ml ${ }^{-1}$ bacterial strains. Then, wells with a diameter of 6-7 mm were punched aseptically with a sterile cork borer or a tip and fish skin mucus extracts and antibiotics $\left(100 \mu \mathrm{ml}^{-1}\right.$ of each crude and aqueous mucus extract per well) were added. For crude and aqueous mucus extracts, positive controls (amikacin and chloramphenicol) were used in concentration of $40 \mu \mathrm{g} \mathrm{ml}^{-1}$ and $20 \mu \mathrm{g} \mathrm{ml}^{-1}$, respectively. The plates were then incubated at $37{ }^{\circ} \mathrm{C}$ for $24 \mathrm{~h}$. Evaluation of bactericidal effect was done by measuring the diameter of the zone of inhibition (ZOI) formed around the well (Jorgensen and Turnidge 2015). The diameter of ZOI was measured in term of millimeter $(\mathrm{mm})$. Antibacterial activity results were compared with two standard antibiotics-amikacin and chloramphenicol (positive control) drug. Physiological saline solution (0.85\% $\mathrm{NaCl}$ ) was used as negative control during aqueous mucus antibacterial assay.

Agar dilutions assay

Minimum inhibitory concentration (MIC) is the lowest concentration of an assayed antimicrobial agent that inhibits the visible growth of bacterium being investigated after overnight incubation. Agar plate dilution test (Wiegand et al. 2008) was used to determine the MIC of HFM and CFM of each fish species against all selected microbial strains. Individual fish skin mucus extract dilution was prepared by dissolving the mucus extract in diluent (sterile distilled water). Dilutions of desired concentrations of fish mucus extracts were prepared and poured in different wells. ZOIs measured at different concentration determine the MICs of different fish mucus extracts against different bacteria.

Statistical analysis

One-way analysis of variance (ANOVA) followed by Duncan's multiple range test (Duncan 1955) was used to determine the significant variation among the mucus of all selected carp species and antibiotics. Student's $t$ test was used to determine the significant difference between ZOIs obtained from HFM and CFM extracts of all selected fish species against different pathogenic strains taken under study. Statistical significance was settled at a probability value of $P<0.05$. All statistics were performed using SPSS Version 11.5 for Windows.

\section{Results}

All selected carps species secreted mucus in variable amounts, which also varied in appearance from species to species. Mucus of $C$. idella was frothy in nature whereas, $C$. carpio secreted yellowish mucus with pungent odor (Table 1). As shown in Table 2, HFM and CFM of C. idella was highest among all three species in summer as well as winter, whereas, low mucus secretion was observed in $H$. nobilis. It was also observed that mucus secretion was higher and more viscous during summer season as compared to winters. After challenge test experiment, all the three carp species studied were found to secrete more viscous mucus and also higher in

Table 2 Amount of mucus extracted from healthy and A. hydrophila challenged experimental fishes in 1-day scrapping (10 attempts at regular intervals)

\begin{tabular}{|c|c|c|c|c|}
\hline \multirow[t]{3}{*}{ Fishes } & \multicolumn{4}{|c|}{ Range of amount of mucus (ml) per day when extracted } \\
\hline & \multicolumn{2}{|l|}{ HFM } & \multicolumn{2}{|l|}{ CFM } \\
\hline & Summer & Winter & Summer & Winter \\
\hline H. nobilis & $4-5$ & $1-2$ & $5-7$ & $4-6$ \\
\hline C. idella & $6-8$ & $4-6$ & $8-9$ & $7-8$ \\
\hline C. carpio & $4-6$ & $3.5-6$ & $6-8$ & $5-8$ \\
\hline
\end{tabular}


volume when compared with HFM (Table 2). Protein content in the fish mucus also varied considerably in different species. Overall trend of protein content in epidermal mucus of all selected healthy fish species was H. nobilis $\quad\left(305.00 \pm 1.64 \mathrm{mg} \mathrm{ml}^{-1}\right)>C$. idella $\quad\left(280.00 \pm 0.00 \mathrm{mg} \mathrm{ml}^{-1}\right)>C$. carpio $\left(100.79 \pm 0.03 \mathrm{mg} \mathrm{ml}^{-1}\right)$. However, the protein concentrations in mucus of all challenged fish species were higher than the mucus of all experimental healthy fishes. Among all challenged fish species, protein content in mucus of $H$. nobilis $\left(378.00 \pm 3.45 \mathrm{mg} \mathrm{ml}^{-1}\right)$ was higher followed by $C$. idella $(346.66 \pm 3.78)$ and $C$. carpio $\left(159.78 \pm 2.19 \mathrm{mg} \mathrm{ml}^{-1}\right)$.

Antibacterial assay

All 12 extracts (1 crude and 1 aqueous HFM and CFM of each fish species) and two antibiotics chloramphenicol and amikacin exhibited strong bactericidal effect against all selected pathogenic strains. Variability between the ZOIs value also appeared within and between the species against all microbial strain taken under study. However, crude mucus extracts of HFM (Table 3) and CFM (Table 5) of all selected fishes exhibited strong inhibitory effect than aqueous mucus extracts of HFM (Table 4) and CFM (Table 6). Difference in mean \pm SE values of ZOI of crude HFM and CFM of all fishes against all microbes were found to be significantly $(P<0.05)$ higher when compared with chloramphenicol. Also crude CFM of $C$. idella $(34.83 \pm 0.13 \mathrm{~mm})$ and $C$. carpio $(33.83 \pm 0.13 \mathrm{~mm})$ exhibited higher ZOI when compared with antibiotic amikacin $(33.33 \pm 0.13 \mathrm{~mm})$ against $P$. aeruginosa as shown in Table 5, whereas, all aqueous mucus extracts of HFM (Table 4) and CFM (Table 6) exhibited significantly lower $(P<0.05)$ bactericidal activity than amikacin. Although aqueous extracts of both (HFM and CFM) of all these three species showed inhibitory effect against all selected microbes, but the ZOI was not remarkably high. No ZOI was shown by physiological saline solution (negative control). The aqueous mucus depicted the lower antibacterial effect against all pathogen studied, and also exhibited different pattern of antibacterial effect against different bacteria. For example, crude mucus of both healthy and A. hydrophila challenged H. nobilis (Tables 3, 5) showed least antibacterial effect against $K$. pneumoniae, but aqueous mucus extract (Tables 4, 6) of same fish showed minimum inhibitory effect against $S$. aureus.

Antibacterial activity of crude and aqueous HFM extracts of all experimental fishes

Photographic images of agar nutrient plates showing ZOIs of crude and aqueous mucus extracts of all selected healthy fishes and two antibiotics against all microbial strains have been presented in Figs. 1, 2, respectively.

Table 3 Zone of inhibition (ZOI) shown by crude HFM extracts of all selected carps species, and two antibiotics against different selected pathogenic microbial strains

\begin{tabular}{|c|c|c|c|c|c|}
\hline \multirow[t]{3}{*}{ Microbial strains } & \multicolumn{5}{|l|}{ ZOI (mm) } \\
\hline & \multicolumn{3}{|l|}{ Fishes } & \multicolumn{2}{|l|}{ Antibiotics } \\
\hline & H. nobilis & C. idella & C. carpio & Chloramphenicol & Amikacin \\
\hline K. pneumoniae & $22.83 \pm 0.13^{\mathrm{Cd}}$ & $26.43 \pm 0.35^{\mathrm{Bc}}$ & $21.50 \pm 0.62^{\mathrm{Cd}}$ & $17.33 \pm 0.27^{\mathrm{Dd}}$ & $33.66 \pm 0.77^{\mathrm{Aab}}$ \\
\hline P. aeruginosa & $28.00 \pm 0.00^{\mathrm{Cb}}$ & $30.00 \pm 0.00^{\mathrm{Ba}}$ & $31.00 \pm 0.00^{\mathrm{Bab}}$ & $18.33 \pm 0.49^{\mathrm{Dd}}$ & $33.33 \pm 0.49^{\mathrm{Aab}}$ \\
\hline E. coli & $31.66 \pm 0.72^{\mathrm{Aa}}$ & $33.66 \pm 0.54^{\mathrm{Aa}}$ & $32.00 \pm 0.00^{\mathrm{Aab}}$ & $25.66 \pm 0.27^{\mathrm{Ba}}$ & $34.00 \pm 0.00^{\text {Aab }}$ \\
\hline S. epidermidis & $32.00 \pm 0.00^{\mathrm{Aa}}$ & $32.00 \pm 0.40^{\mathrm{Aa}}$ & $27.66 \pm 0.13^{\mathrm{Bc}}$ & $21.16 \pm 1.83^{\mathrm{Cbc}}$ & $31.66 \pm 0.27^{\mathrm{Ac}}$ \\
\hline S. aureus & $29.33 \pm 0.13^{\mathrm{Bb}}$ & $29.00 \pm 0.00^{\mathrm{Bc}}$ & $24.00 \pm 0.81^{\mathrm{Cd}}$ & $22.66 \pm 0.72^{\mathrm{Cb}}$ & $31.66 \pm 0.13^{\mathrm{Ac}}$ \\
\hline B. cereus & $29.03 \pm 0.25^{\mathrm{Cb}}$ & $29.83 \pm 0.25^{\mathrm{Cb}}$ & $32.80 \pm 0.09^{\mathrm{Ba}}$ & $25.43 \pm 0.43^{\mathrm{Da}}$ & $34.33 \pm 0.27^{\mathrm{Aa}}$ \\
\hline A. hydrophila & $26.16 \pm 0.13^{\mathrm{Cc}}$ & $29.67 \pm 0.15^{\mathrm{Bb}}$ & $29.13 \pm 0.47^{\mathrm{Bbc}}$ & $20.00 \pm 0.23^{\mathrm{Dc}}$ & $33.33 \pm 0.27^{\mathrm{Abc}}$ \\
\hline
\end{tabular}

Zone of inhibition including well diameter

All values are mean $\pm \mathrm{SE}$ of mean

Means with different letters in upper case in the same row are significantly $(P<0.05)$ different

Means with different letters in lower case in the same column are significantly $(P<0.05)$ different

Data were analyzed by Duncan's multiple range test 
Table 4 Zone of inhibition (ZOI) shown by aqueous HFM extracts of all carps species, and two antibiotics against different selected pathogenic microbial strains

\begin{tabular}{|c|c|c|c|c|c|}
\hline \multirow[t]{3}{*}{ Microbial strains } & \multicolumn{5}{|l|}{$\mathrm{ZOI}(\mathrm{mm})$} \\
\hline & \multicolumn{3}{|l|}{ Fishes } & \multicolumn{2}{|l|}{ Antibiotics } \\
\hline & H. nobilis & C. idella & C. carpio & Chloramphenicol & Amikacin \\
\hline K. pneumoniae & $14.33 \pm 0.27^{\mathrm{Ca}}$ & $16.33 \pm 0.13^{\mathrm{Ba}}$ & $13.00 \pm 0.00^{\mathrm{Dbc}}$ & $10.00 \pm 0.00^{\mathrm{Ec}}$ & $24.23 \pm 0.50^{\mathrm{Aa}}$ \\
\hline P. aeruginosa & $12.30 \pm 0.12^{\mathrm{Bd}}$ & $13.80 \pm 0.49^{\mathrm{Bb}}$ & $12.83 \pm 0.45^{\mathrm{Bb}}$ & $08.73 \pm 0.70^{\mathrm{Cb}}$ & $22.56 \pm 0.58^{\mathrm{Ab}}$ \\
\hline E. coli & $14.10 \pm 0.37^{\mathrm{BCbc}}$ & $15.21 \pm 1.08^{\mathrm{Bb}}$ & $14.43 \pm 0.19^{\mathrm{BCb}}$ & $12.70 \pm 0.30^{\mathrm{Ca}}$ & $23.86 \pm 0.48^{\mathrm{Aab}}$ \\
\hline S. epidermidis & $14.26 \pm 0.28^{\mathrm{Bab}}$ & $14.60 \pm 0.32^{\mathrm{Bb}}$ & $12.63 \pm 0.29^{\mathrm{Cc}}$ & $10.10 \pm 0.04^{\mathrm{Db}}$ & $20.56 \pm 0.43^{\mathrm{Ac}}$ \\
\hline S. aureus & $11.00 \pm 0.00^{\mathrm{Bc}}$ & $08.90 \pm 0.79^{\mathrm{CDc}}$ & $08.00 \pm 0.40^{\mathrm{Dd}}$ & $10.06 \pm 0.05^{\mathrm{BCb}}$ & $20.06 \pm 0.05^{\mathrm{Ac}}$ \\
\hline B. cereus & $13.70 \pm 0.53^{\mathrm{Cc}}$ & $14.26 \pm 0.14^{\mathrm{BCb}}$ & $14.83 \pm 0.17^{\mathrm{Ba}}$ & $12.13 \pm 0.10^{\mathrm{Da}}$ & $20.33 \pm 0.13^{\mathrm{Ac}}$ \\
\hline A. hydrophila & $13.40 \pm 0.65^{\mathrm{Bcd}}$ & $13.70 \pm 0.46^{\mathrm{Bb}}$ & $13.50 \pm 0.62^{\mathrm{Bbc}}$ & $12.76 \pm 0.24^{\mathrm{Ba}}$ & $19.33 \pm 0.27^{\mathrm{Ac}}$ \\
\hline
\end{tabular}

Zone of inhibition including well diameter

All values are mean \pm SE of mean

Means with different letters in upper case in the same row are significantly $(P<0.05)$ different

Means with different letters in lower case in the same column are significantly $(P<0.05)$ different

Data were analyzed by Duncan's multiple range test

Table 5 Zone of inhibition (ZOI) shown by crude CFM extracts of all selected fishes, and two antibiotics against different selected pathogenic microbial strains

\begin{tabular}{|c|c|c|c|c|c|}
\hline \multirow[t]{3}{*}{ Microbial strains } & \multicolumn{5}{|l|}{$\mathrm{ZOI}(\mathrm{mm})$} \\
\hline & \multicolumn{3}{|l|}{ Fishes } & \multicolumn{2}{|l|}{ Antibiotics } \\
\hline & H. nobilis & C. idella & C. carpio & Chloramphenicol & Amikacin \\
\hline K. pneumoniae & $25.20 \pm 1.14^{\mathrm{Cd}}$ & $28.61 \pm 0.50^{\mathrm{Bd}}$ & $26.80 \pm 0.12^{\mathrm{BCd}}$ & $18.00 \pm 0.00^{\mathrm{Dd}}$ & $34.00 \pm 0.00^{\text {Aab }}$ \\
\hline P. aeruginosa & $29.33 \pm 0.50^{\mathrm{Bb}}$ & $34.33 \pm 0.13^{\mathrm{Aa}}$ & $33.83 \pm 0.13^{\mathrm{Aab}}$ & $17.66 \pm 0.27^{\mathrm{Cd}}$ & $33.33 \pm 0.13^{\mathrm{Abc}}$ \\
\hline E. coli & $31.00 \pm 0.47^{\mathrm{Ca}}$ & $33.33 \pm 0.54^{\mathrm{ABa}}$ & $33.33 \pm 0.19^{\mathrm{Bab}}$ & $25.33 \pm 0.27^{\mathrm{Cb}}$ & $34.28 \pm 0.13^{\text {Aab }}$ \\
\hline S. epidermidis & $30.50 \pm 0.23^{\mathrm{Ba}}$ & $32.83 \pm 0.82^{\mathrm{Aa}}$ & $29.53 \pm 0.60^{\mathrm{Bc}}$ & $21.66 \pm 0.72^{\mathrm{Cbc}}$ & $33.66 \pm 0.27^{\mathrm{Ac}}$ \\
\hline S. aureus & $28.66 \pm 0.72^{\mathrm{Bb}}$ & $29.00 \pm 0.00^{\mathrm{Bbc}}$ & $27.13 \pm 0.85^{\mathrm{Bd}}$ & $21.66 \pm 0.27^{\mathrm{Cb}}$ & $33.83 \pm 0.13^{\mathrm{Ac}}$ \\
\hline B. cereus & $29.83 \pm 0.13^{\mathrm{Cb}}$ & $31.00 \pm 0.47^{\mathrm{Bb}}$ & $34.00 \pm 0.00^{\mathrm{Aa}}$ & $25.23 \pm 0.19^{\mathrm{Da}}$ & $34.66 \pm 0.27^{\mathrm{Aa}}$ \\
\hline A. hydrophila & $26.00 \pm 0.47^{\mathrm{Dc}}$ & $30.33 \pm 0.54^{\mathrm{Cb}}$ & $32.00 \pm 0.00^{\mathrm{Bbc}}$ & $20.66 \pm 0.54^{\mathrm{Ec}}$ & $33.66 \pm 0.27^{\mathrm{Abc}}$ \\
\hline
\end{tabular}

Zone of inhibition including well diameter

All values are mean \pm SE of mean

Means with different letters in upper case in the same row are significantly $(P<0.05)$ different

Means with different letters in lower case in the same column are significantly $(P<0.05)$ different

Data were analyzed by Duncan's multiple range test

ZOIs values of crude and aqueous HFM extracts were in the ranges of $21.50 \pm 0.62 \mathrm{~mm}$ to $33.66 \pm 0.54 \mathrm{~mm}$ (Table 3) and $08.00 \pm 0.40 \mathrm{~mm}$ to $15.21 \pm 1.08 \mathrm{~mm}$ (Table 4), respectively.

In case of crude mucus extracts, as depicted in Table 3 and Fig. 1a-g, among all the selected bacterial strains, HFM of $H$. nobilis exhibited higher bactericidal effect $(32.00 \pm 0.00 \mathrm{~mm})$ against $S$. epidermidis which was also significantly $(P<0.05)$ higher than both antibiotics amikacin $(31.66 \pm 0.27 \mathrm{~mm})$ and chloramphenicol $(17.33 \pm 0.27 \mathrm{~mm})$, whereas, mucus of $C$. idella showed maximum ZOI $(33.66 \pm 0.54 \mathrm{~mm})$ against $E$. coli. At the same time, mucus of $C$. carpio effectively inhibited the growth of B. cereus by showing ZOI of $32.80 \pm 0.09 \mathrm{~mm}$. However, mucus of all experimental fishes was found to be less effective against $K$. pneumoniae as shown in Fig. 1a. As shown in Table 4 and Fig. 2a-g, for aqueous mucus extracts; HFM of both $H$. nobilis $(14.33 \pm 0.27 \mathrm{~mm})$ and $C$. idella $(16.33 \pm 0.13 \mathrm{~mm})$ showed maximum inhibitory effect against $K$. pneumoniae among all microbial strains studied. Here also, like crude 
Table 6 Zone of inhibition (ZOI) shown by aqueous CFM extracts of all carps species, and two antibiotics against different selected pathogenic microbial strains

\begin{tabular}{|c|c|c|c|c|c|}
\hline \multirow[t]{3}{*}{ Microbial strains } & \multicolumn{5}{|l|}{$\mathrm{ZOI}(\mathrm{mm})$} \\
\hline & \multicolumn{3}{|l|}{ Fishes } & \multicolumn{2}{|l|}{ Antibiotics } \\
\hline & H. nobilis & C. idella & C. carpio & Chloramphenicol & Amikacin \\
\hline K. pneumoniae & $16.16 \pm 0.65^{\mathrm{Ca}}$ & $18.50 \pm 0.66^{\mathrm{Ba}}$ & $14.73 \pm 0.34^{\mathrm{Cbc}}$ & $10.23 \pm 0.31^{\mathrm{Dd}}$ & $24.86 \pm 0.87^{\mathrm{Aa}}$ \\
\hline P. aeruginosa & $11.76 \pm 0.35^{\mathrm{Cd}}$ & $14.96 \pm 0.16^{\mathrm{Bb}}$ & $16.33 \pm 1.18^{\mathrm{Bb}}$ & $09.33 \pm 0.27^{\mathrm{Cc}}$ & $22.00 \pm 0.94^{\mathrm{Ab}}$ \\
\hline E. coli & $13.93 \pm 0.47^{\mathrm{Cbc}}$ & $16.33 \pm 0.27^{\mathrm{Bb}}$ & $14.66 \pm 0.68^{\mathrm{BCb}}$ & $13.66 \pm 0.54^{\mathrm{Ca}}$ & $25.00 \pm 0.00^{\mathrm{Aa}}$ \\
\hline S. epidermidis & $15.76 \pm 0.32^{\mathrm{Bab}}$ & $16.40 \pm 0.09^{\mathrm{Bb}}$ & $12.86 \pm 0.10^{\mathrm{Cc}}$ & $12.33 \pm 0.27^{\mathrm{Cc}}$ & $23.33 \pm 0.27^{\mathrm{Abc}}$ \\
\hline S. aureus & $10.40 \pm 0.60^{\mathrm{BCc}}$ & $11.20 \pm 0.49^{\mathrm{Bc}}$ & $08.66 \pm 0.27^{\mathrm{Cd}}$ & $10.33 \pm 0.27^{\mathrm{BCd}}$ & $21.00 \pm 0.47^{\mathrm{Acd}}$ \\
\hline B. cereus & $13.63 \pm 0.29^{\mathrm{Dc}}$ & $15.76 \pm 0.43^{\mathrm{Cb}}$ & $17.73 \pm 0.43^{\mathrm{Ba}}$ & $11.96 \pm 0.44^{\mathrm{Ebc}}$ & $20.66 \pm 0.27^{\text {Acd }}$ \\
\hline A. hydrophila & $12.60 \pm 0.24^{\mathrm{Ccd}}$ & $14.66 \pm 0.27^{\mathrm{Bb}}$ & $15.26 \pm 0.11^{\mathrm{Bbc}}$ & $12.66 \pm 0.27^{\mathrm{Cab}}$ & $19.33 \pm 0.54^{\mathrm{Ad}}$ \\
\hline
\end{tabular}

Zone of inhibition including well diameter

All values are mean \pm SE of mean

Means with different letters in upper case in the same row are significantly $(P<0.05)$ different

Means with different letters in lower case in the same column are significantly $(P<0.05)$ different

Data were analyzed by Duncan's multiple range test

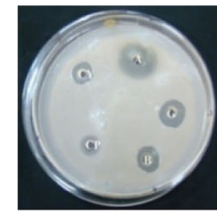

(a)

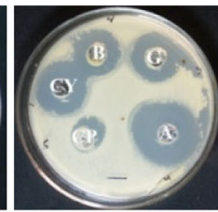

(b)

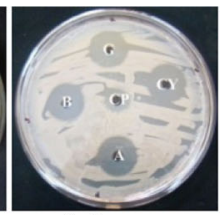

(c)

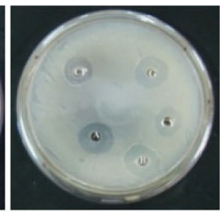

(d)

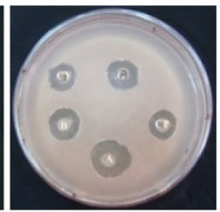

(e)

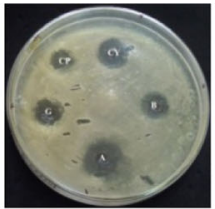

(f)

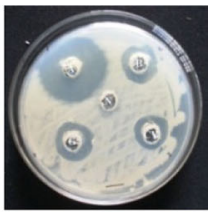

(g)

Fig. 1 Zone of inhibition shown by crude HFM extracts of all experimental fishes against all selected pathogenic bacterial strains, a $K$. pneumoniae, b $P$. aeruginosa, c E. coli, $\mathbf{d} S$. epidermidis, e $S$. aureus, $\mathbf{f}$ B. cereus, and $\mathbf{g}$ A. hydrophila

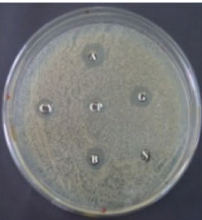

(a)

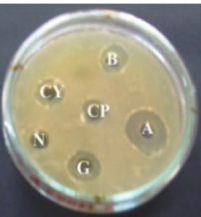

(b)

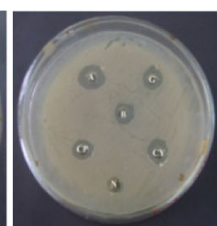

(c)

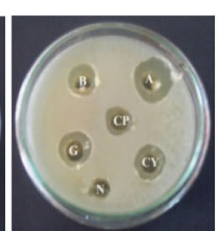

(d)

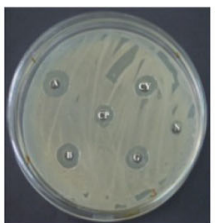

(e)

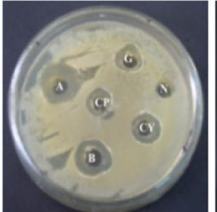

(f)

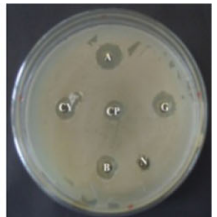

(g)

Fig. 2 Zone of inhibition shown by aqueous HFM extracts of all experimental fishes against all selected pathogenic bacterial strains, a K. pneumoniae, b P. aeruginosa, c E. coli, d S. epidermidis, e S. aureus, $\mathbf{f}$ B. cereus, and $\mathbf{g}$ A. hydrophila

mucus extract, C. carpio $(14.83 \pm 0.17 \mathrm{~mm})$ was most effective against $B$. cereus indicated by Fig. $2 \mathrm{f}$. Whereas, all experimental fishes exhibited minimum ZOIs against $S$. aureus as shown by Fig. 2e.

Antibacterial activity of crude and aqueous CFM extracts of all experimental fishes

Antibacterial effect of crude CFM extracts of all selected exotic carps and two antibiotics (amikacin and chloramphenicol) against all microbial strains were in the range of $25.20 \pm 1.14 \mathrm{~mm}$ to $34.33 \pm 0.13 \mathrm{~mm}$ (Table 5). Whereas, ZOI values for aqueous CFM mucus extracts ranges from $08 \pm 0.27$ to $18.50 \pm 0.66 \mathrm{~mm}$ has been presented in Table 6. Photographic images of agar plates showing ZOIs of crude and aqueous mucus extracts of all selected challenged fishes and two antibiotics against all selected bacterial strain have been depicted in Figs. 3a-g, 4a-g, respectively. 
In case of crude mucus extracts (Table 5), mucus obtained from H. nobilis exhibited maximum inhibitory effect $(31.00 \pm 0.47 \mathrm{~mm})$ against $E$. coli among all selected pathogens. The mucus of $C$. idella was found to be most effective against $P$. aeruginosa with ZOI of $34.33 \pm 0.13 \mathrm{~mm}$ which was also significantly higher $(P<0.05)$ when compared with amikacin $(33.33 \pm 0.13 \mathrm{~mm})$. Like HFM, CFM of $C$. carpio (34.00 $\pm 0.00 \mathrm{~mm}$ ) most effectively inhibited the growth of $B$. cereus as compared to other selected microbial strains. All exotic carps showed minimum antibacterial effect against $K$. pneumoniae as shown by Fig. 3a. In case of aqueous mucus extracts also (Table 6), CFM of $H$. nobilis $(16.16 \pm 0.65 \mathrm{~mm})$ and $C$. idella $(18.50 \pm 0.66 \mathrm{~mm})$ exhibited maximum bactericidal effect against $K$. pneumoniae among all selected bacteria. These ZOIs values were significantly higher $(P<0.05)$ than antibiotic chloramphenicol. On the other hand, CFM of $C$. carpio $(17.73 \pm 0.43 \mathrm{~mm})$ strongly inhibited the growth of B. cereus among all microbial strains. However, all experimental fishes showed minimum ZOIs against $S$. aureus (Fig. 4e).

Comparison between antibacterial effect shown by HFM and CFM extracts of all selected experimental fishes

In case of crude HFM and CFM of all experimental fishes, as depicted in Fig. 5a, antibacterial effect shown by crude HFM of $H$. nobilis was also found to be higher than CFM against E. coli, S. epidermidis, S. aureus and A. hydrophila. But, in case of $K$. pneumoniae, $P$. aeruginosa and B. cereus; CFM was more effective than HFM. Statistically significant $(P<0.05)$ differences were observed in the mean \pm SE values of HFM and CFM extracts against $K$. pneumoniae and S. epidermidis among all bacteria studied. As shown in Fig. 5c, ZOI values of CFM of $C$. idella were found to be higher than HFM against $K$. pneumoniae, $P$. aeruginosa, $S$. epidermidis, B. cereus and A. hydrophila, whereas, in case of E. coli, HFM was more effective than CFM. Furthermore, CFM and HFM of $C$. idella exhibited similar bactericidal effect against $S$. aureus. Mean $\pm \mathrm{SE}$ values of HFM and CFM extracts were found to be statistically different $(P<0.5)$ in case of $K$. pneumoniae and $S$. epidermidis. For $C$. carpio Fig. 5e, ZOI values of CFM extracts were found to be higher than HFM extracts against all selected microbes. Mean \pm SE values of HFM and CFM extracts were found to be statistically significantly different $(P<0.5)$ against $K$. pneumoniae and $P$. aeruginosa.

In case of aqueous mucus extracts of healthy and challenged fishes, as shown in Fig. 5b, HFM of H. nobilis, was more effective than CFM against P. aeruginosa, E. coli, S. aureus, and B. cereus. But in all other bacterial strains studied, CFM was found to be higher than HFM. The difference in mean \pm SE values of ZOI of HFM and CFM extracts were found to be statistically significant $(P<0.05)$ against two pathogens viz. K. pneumoniae and S. epidermidis among all selected microbes. For mucus extracts of $C$. idella as depicted in Fig. 5d, CFM extract exhibited higher bactericidal effect than HFM against all bacterial strains studied. But the statistically significant $(P<.05)$ difference in mean \pm SE values of ZOIs of HFM and CFM were observed against $K$. pneumoniae, S. epidermidis and $S$. aureus among all selected bacteria. ZOIs values of CFM extracts of $C$. carpio showed higher bactericidal effect than HFM against all selected microbial strains. But the difference in ZOI values of HFM and CFM extracts were found to be statistically significant $(P<0.05)$ against three pathogenic strains viz. K. pneumoniae, $P$. aeruginosa and B. cereus only as shown in Fig. $5 f$.

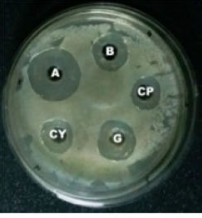

(a)

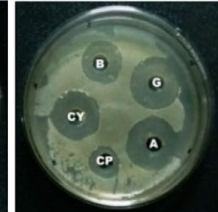

(b)

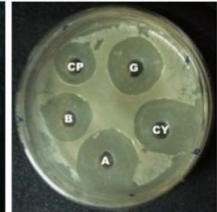

(c)

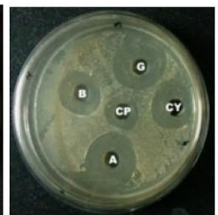

(d)

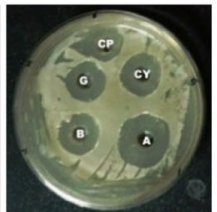

(e)

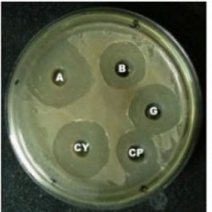

(f)

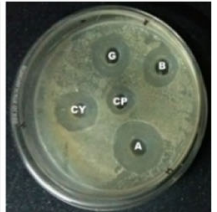

(g)

Fig. 3 Zone of inhibition shown by crude CFM extracts of all experimental fishes against all selected pathogenic bacterial strains, a K. pneumoniae, b $P$. aeruginosa, c E. coli, $\mathbf{d}$ S. epidermidis, e $S$. aureus, $\mathbf{f}$ B. cereus, and $\mathbf{g}$ A. hydrophila 


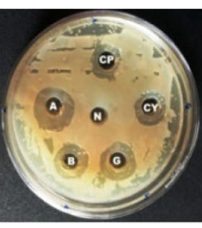

(a)

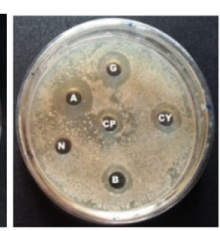

(b)

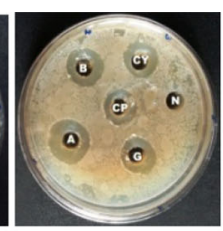

(c)

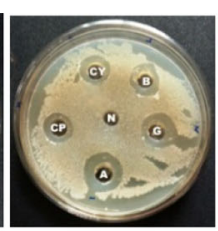

(d)

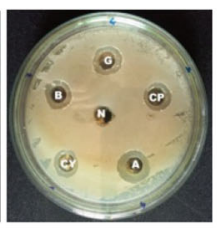

(e)

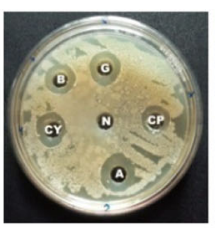

(f)

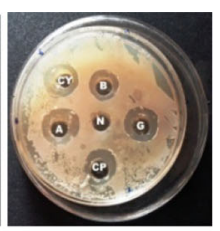

(g)

Fig. 4 Zone of inhibition shown by aqueous CFM extracts of all experimental fishes against all selected pathogenic bacterial strains, a K. pneumoniae, b $P$. aeruginosa, c E. coli, $\mathbf{d} S$. epidermidis, e $S$. aureus, $\mathbf{f}$ B. cereus, and $\mathbf{g}$ A. hydrophila. (Asterisk) Capital letters marked on agar nutrient plates denotes-A, amikacin; B, H. nobilis; CP, chloramphenicol; G, C. idella; CY, C. carpio, $\mathrm{N}$, physiological saline solution $(\mathrm{NaCl})$ (negative control, used only in aqueous agar plates). (Asterisk) Values are significantly different $(P<0.05)$ (Student's $t$ test)

MIC assay

Different fish mucus extracts showed different MICs against different selected microbial strains. Both extracts (HFM and CFM) of all experimental fishes showed MIC at $25 \mu \mathrm{lm}^{-1}$ against $K$. pneumoniae, E. coli and B. cereus and $50 \mu \mathrm{l} \mathrm{ml}^{-1}$ against $P$. aeruginosa, S. epidermidis, S. aureus and A. hydrophila (Table 7).

\section{Discussion}

The present studies revealed that all the three carp species (H. nobilis, $C$. idella and $C$. carpio) investigated secreted huge amount of mucus and the volume of secretion varied among the three. These results are similar to studies of Nigam et al. (2012) for different fish species viz. Cirrhinus mrigala, Labeo rohita, Catla catla, Rita rita, and Channa punctata. These variations in mucus secretion may be attributed to the different ecological and physiological conditions and also to different mucus producing cells situated in epidermis and epidermal layers of different fish species. Jung et al. (2012) had also shown the variation in mucus secretion and its components during the summer and winter months, which also supports our finding as mucus secretion was higher in carps studied during summers than in winter months. Present study also revealed more dense and increased amount of mucus in all fish species, after challenging with A. hydrophila. This increased mucus secretion may be an indicator of increased stress level and activation of innate immune system against bacterial attack. Many previous reports (Subramanian et al. 2008; Nigam et al. 2012) demonstrated that environmental perturbations such as, $\mathrm{pH}$, temperature, dissolved oxygen, different ecological niches, bacterial stress, different developmental stages also influence the amount of mucus secretion in fishes. Our results are in substantial agreement with these studies. Jones (2001) also reported that Gyrodactylus infected fish produced high amount of mucus than healthy fish which also supports our finding that increased bacterial stress enhanced mucus secretion in challenged group. Subramanian et al. (2008) and Holm et al. (2015) also observed similar results.

It is now well established that fish skin mucus acts as mechanical barrier to fishes by lying at interface between them and surrounding pathogens (Reverter et al. 2018). In addition to trapping and sloughing of infectious pathogens, the skin mucus is the reservoir of antimicrobial components which acts in different ways and is gifted with innate antibacterial ability as reported by Nagashima et al. (2001). Furthermore, predominantly proteinaceous nature of the skin mucus secretions of different fish species viz. Anguilla japonica, Arius maculates, and Channa striatus has been reported by many authors such as Chong et al. (2005) and Manivasagan et al. (2009) etc. This high protein content could be associated with mucosal innate immunity because most of bactericidal components identified in fish mucus, are also proteinous in nature. Arulvasu et al. (2012), demonstrated that crude and partially purified epidermal mucus of Tachysurus dussumieri have $0.48 \pm 0.02 \mathrm{mg} \mathrm{ml}^{-1}$ and $0.82 \pm 0.05 \mathrm{mg} \mathrm{ml}^{-1}$ protein content. Similarly, Rao et al. (2015) have also investigated the protein as major constituent among different skin mucus extracts (crude, acidic, and organic) of C. micropeltes, C. striatus, Oreochromis niloticus, and Mystus nemurus. Protein quantification results revealed that crude mucus extracts of all fish species contained a high amount of proteins ranging from $432.90 \pm 28.20$ to $579.90 \pm 32.30 \mu \mathrm{g} \mathrm{ml}^{-1}$ when compared with other extracts. Our results are also in 


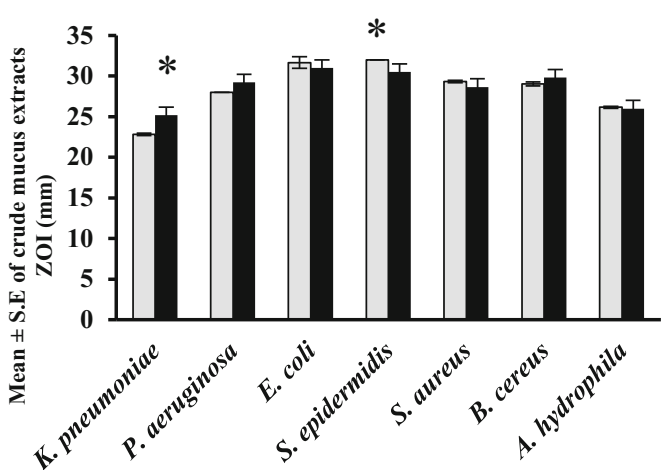

(a)

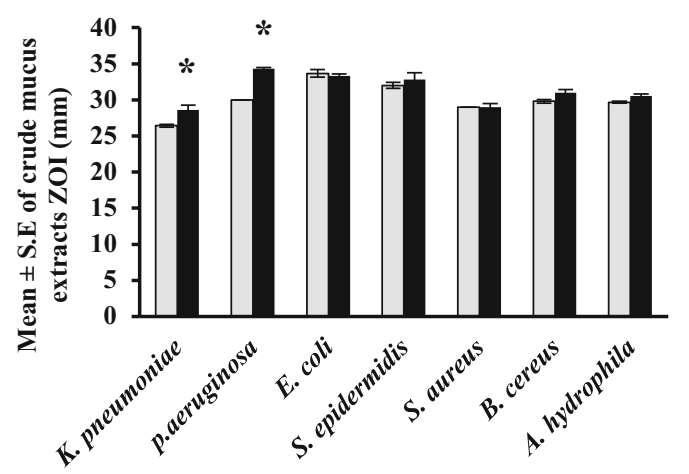

(c)

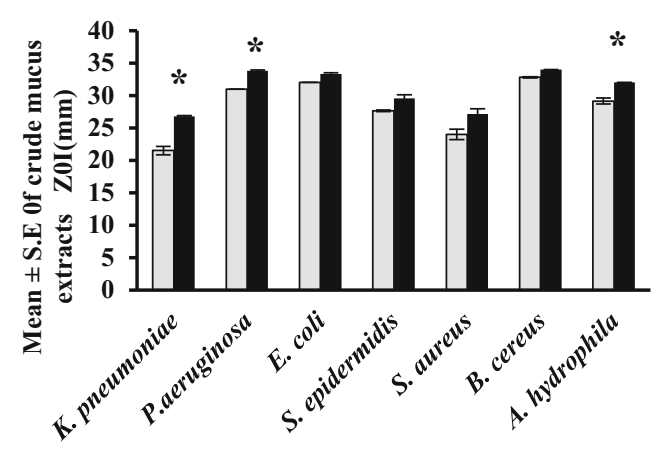

(e)

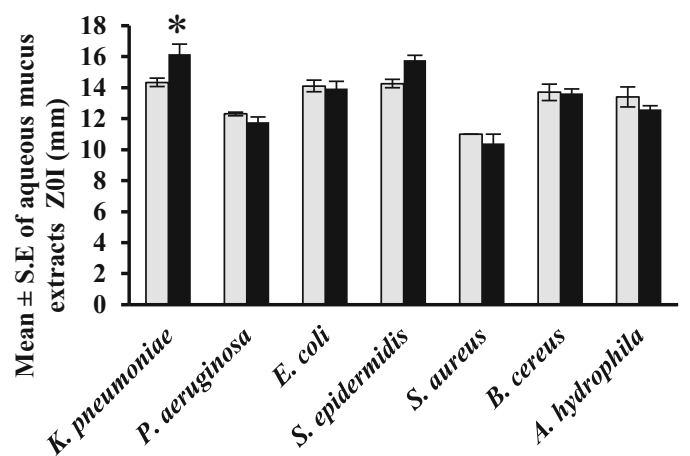

(b)

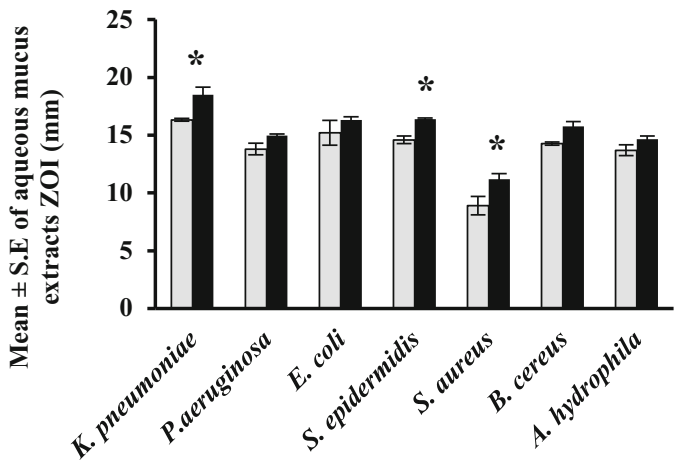

(d)

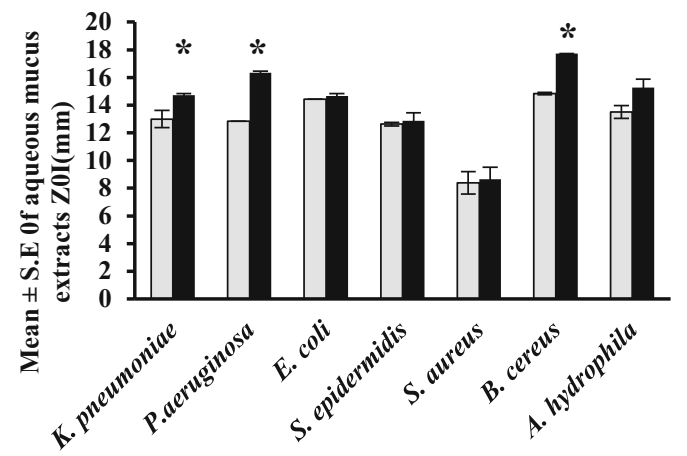

(f)

HFM

\section{CFM}

*Values are significantly different $(P<0.05)$ (student't' test)

Fig. 5 Comparison of antibacterial effect of HFM and CFM extracts all selected fishes against all selected microbes where $\mathbf{a}$ crude and $\mathbf{b}$ aqueous extracts of $H$. nobilis, $\mathbf{c}$ crude and $\mathbf{d}$ aqueous mucus extracts of $C$. idella and $\mathbf{e}$ crude and $\mathbf{f}$ aqueous extracts of C. carpio

agreement with above studies. However, in present study, protein content ranges from $100.79 \pm 0.03$ to $305.00 \pm 1.64 \mathrm{mg} \mathrm{ml}^{-1}$ for HFM and $159.78 \pm 2.19 \mathrm{mg} \mathrm{ml}^{-1}$ to $378.00 \pm 3.45 \mathrm{mg} \mathrm{ml}^{-1}$ for CFM. The presence of comparatively high proteins content in our study might be due to the species difference and environmental factors such as water quality $\left(\mathrm{DO}, \mathrm{CO}_{2}\right.$, ammonia, $\left.\mathrm{pH}\right)$ and the presence of contaminants. Our results also revealed that protein content not only vary with in the species (between HFM and CFM extracts), but also among species in both extracts (HFM and CFM). Also CFM extracts of all selected fish species 
Table 7 MIC and ZOI shown by HFM and CFM of selected carps species against all microbial strain

\begin{tabular}{|c|c|c|c|c|c|}
\hline \multirow[t]{2}{*}{ Microbial strains } & \multirow[t]{2}{*}{$\operatorname{MIC}\left(\mu 1 \mathrm{ml}^{-1}\right)$} & \multirow[t]{2}{*}{ Mucus extracts } & \multicolumn{3}{|c|}{ Fishes ZOI (mm) } \\
\hline & & & H. nobilis & C. idella & C. carpio \\
\hline \multirow[t]{2}{*}{ K. pneumoniae } & \multirow[t]{2}{*}{25} & HFM & $07.00 \pm 0.00$ & $07.93 \pm 0.27$ & $07.06 \pm 0.05$ \\
\hline & & CFM & $07.26 \pm 0.14$ & $08.40 \pm 0.12$ & $09.03 \pm 0.11$ \\
\hline \multirow[t]{2}{*}{$P$. aeruginosa } & \multirow[t]{2}{*}{50} & HFM & $12.30 \pm 0.12$ & $13.80 \pm 0.47$ & $12.83 \pm 0.45$ \\
\hline & & CFM & $11.76 \pm 0.35$ & $14.96 \pm 0.16$ & $16.33 \pm 1.18$ \\
\hline \multirow[t]{2}{*}{ E. coli } & \multirow[t]{2}{*}{25} & HFM & $07.00 \pm 0.00$ & $08.00 \pm 0.94$ & $07.03 \pm 0.02$ \\
\hline & & CFM & $06.50 \pm 0.27$ & $07.80 \pm 0.30$ & $08.60 \pm 0.28$ \\
\hline \multirow[t]{2}{*}{ S. epidermidis } & \multirow[t]{2}{*}{50} & HFM & $14.26 \pm 0.28$ & $14.60 \pm 0.32$ & $12.63 \pm 0.29$ \\
\hline & & CFM & $15.76 \pm 0.32$ & $16.40 \pm 0.94$ & $12.86 \pm 0.01$ \\
\hline \multirow[t]{2}{*}{ S. aureus } & \multirow[t]{2}{*}{50} & HFM & $11.00 \pm 0.00$ & $08.90 \pm 0.79$ & $08.40 \pm 0.40$ \\
\hline & & CFM & $10.40 \pm 0.60$ & $11.10 \pm 0.49$ & $08.66 \pm 0.27$ \\
\hline \multirow[t]{2}{*}{ B. cereus } & \multirow[t]{2}{*}{25} & HFM & $06.00 \pm 0.24$ & $06.00 \pm 0.00$ & $07.00 \pm 0.00$ \\
\hline & & CFM & $06.03 \pm 0.52$ & $07.03 \pm 0.07$ & $07.76 \pm 0.67$ \\
\hline \multirow[t]{2}{*}{ A. hydrophila } & \multirow[t]{2}{*}{50} & HFM & $13.40 \pm 0.65$ & $13.70 \pm 0.46$ & $13.50 \pm 0.09$ \\
\hline & & CFM & $12.60 \pm 0.24$ & $14.66 \pm 0.27$ & $15.26 \pm 0.11$ \\
\hline
\end{tabular}

Zone of inhibition including well diameter

All values are mean $\pm \mathrm{SE}$ of mean

showed higher protein content than HFM. Subramanian et al. (2008) had also revealed that extruded slime (secreted during a bacterial stress/after feeding/active swimming) exhibited higher protein concentration than normal epidermal mucus. They also stated that the mucus producing cells in epidermal and epithelial layers differ between fish species and, therefore, could influence the mucus composition. Furthermore, the biochemical substances of mucus appear to differ depending on the ecological and physiological condition, handling stress and stages of growth and maturity. Present results on antibacterial activity shown by selected exotic carps also confirm that fish mucus is a source of antimicrobial products. Earlier studies by many authors (Balasubramanian et al. 2012; Prakash et al. 2013; Nurtamin et al. 2016) have also demonstrated strong antibacterial activity in several fishes. Ebran et al. (2000) stated that only the hydrophobic components of crude epidermal mucus of fresh water and sea water fish exhibited strong pore-forming properties, which were well correlated with antibacterial activity. Manivasagan et al. (2009) also reported the antibacterial activity in skin mucus soluble and insoluble fraction of A. maculatus and A. thallasinus against $E$. coli and $P$. aeruginosa. Wei et al. (2010) reported that crude mucus extract of $C$. striatus showed ZOI of $8 \mathrm{~mm}$ against $A$. hydrophila and no antibacterial effect against $E$. coli and $K$. pneumoniae. However, ZOIs values against same microbes shown by mucus extracts in our study were higher. Bragadeeswaran and Thangaraj (2011) had revealed the strong antimicrobial effect of crude mucus extract of Angullia. Angullia against E. coli, P. aeruginosa and S. aureus and no activity was seen against $K$. pneumoniae. Furthermore, they did not notice bactericidal effect in aqueous mucus extract against $P$. aeruginosa. However, in the present studies, crude mucus, as well as aqueous mucus (HFM and CFM) extracts from all the three selected fish species, exhibited antibacterial activity against all these microbial strains. Variation in antibacterial activity of mucus might be due to different fish species, different habitats, different stress levels, etc. Further, different fishes may be having different susceptibility against different or same pathogen/s. Expression of different immune components in different fish species against different pathogens could be due to variations in bactericidal effect. Subramanian et al. (2007) also reported antimicrobial activity of aqueous mucus extract of several fish species. However, in subsequent studies; they could not observe any bactericidal effect in aqueous mucus extract of a wide range of fish species such as S. alpines, S. fontinalis, C. carpio, M. saxatilis, M. aeglefinus, and M. glutinosa. Lower enzymatic activities due to incubation temperature or $\mathrm{pH}$ conditions used in the antimicrobial assay might be the reasons behind the absence of antibacterial activity. But in the present study, aqueous mucus extracts of all selected fish species exhibited bactericidal effect against all the pathogenic bacteria used in the investigations. 
Anbuchezhian et al. (2011) also observed similar results which lend support to our investigations. In our studies, concentration of mucus in aqueous extracts (in both HFM and CFM) of all selected fish species was half than crude mucus extracts. It was expected that pattern of antimicrobial effect should be lower (that means $50 \%$ ) in aqueous extracts. But this was not observed. Moreover, results indicated that aqueous mucus not only depicted the lower antibacterial effect against all pathogen studied, but also exhibited different pattern of antibacterial effect against different bacteria. For example, crude mucus of both healthy and $A$. hydrophila challenged $H$. nobilis (Tables 3,5 ) showed least antibacterial effect against $K$. pneumoniae but aqueous mucus extract (Tables 4, 6) of same fish showed minimum inhibitory effect against $S$. aureus. This could be due to different susceptibility/responsiveness of mucus against different microorganisms under its different concentrations.

Study of Kumari et al. (2011) revealed that aqueous mucus extracts of $R$. rita and C. punctatus exhibited ZOIs of $9.75 \pm 1.70 \mathrm{~mm}$ and $8.00 \pm 0.47 \mathrm{~mm}$ against $S$. arueus. In the same study, aqueous mucus of both fishes was not effective against $E$. coli and $P$. aeruginosa. However, their report on low ZOIs values against $S$. aureus was similar to present results. Balasubramanian et al. (2012) demonstrated the antibacterial effect shown by the mucus of $C$. idella against E. coli $(17 \mathrm{~mm}), K$. pneumoniae $(7 \mathrm{~mm})$ and P. aeruginosa $(15 \mathrm{~mm})$. Our findings on aqueous HFM and CFM are also similar to those reported by Balasubramanian et al. (2012). It is evident from this discussion that different fish species exhibit variation in their antibacterial activity against similar or different microbial strains which might be due to difference in quality and quantity of proteins/ enzymes in secreted mucus.

Hellio et al. (2002) had investigated the antibacterial effects of the aqueous mucus extracts of 13 fish species and did not observe any antibacterial activity; however, these authors did not study the properties of crude mucus extract. Similarly, strong inhibitory effect of acidic mucus extracts of Tilapia and bagrid catfish against human pathogenic bacteria was reported by Rao et al. (2015), whereas, they failed to observe any bactericidal effect in crude and aqueous mucus extracts.

Current investigations observed a change in antibacterial activity (either increased or decreased) after bacterial challenge. Subramanian et al. (2009) also reported that extruded slime produced by bacterial stress had higher bactericidal effect than normal mucus in M. glutinosa L. Raj et al. (2011) observed increased antibacterial activity in mucus of $C$. carpio after virus infection. Our studies are in agreement with these studies. Furthermore, this increased or decreased inhibitory effect in fish species might be due to different enzymes level or different protein secretion in same or different fish species, during adverse conditions.

Antibacterial activities shown by HFM and CFM of the carp species studied; clearly indicate the presence of antimicrobial compounds in fish epidermal mucus. Lirio et al.(2018) reported that antibacterial components act non-specifically; they forms pore in cell membrane of target bacteria; release cell-content and finally leads to cell lyses. Thus, we may assume that pore formation properties of antimicrobial compounds present in skin mucus may be responsible for the strong antibacterial effect.

Many authors (Wei et al. 2010; Vennila et al. 2011; Rao et al. 2015) had studied the MICs of skin mucus extracts of $C$. striatus, Dasyatis sephen and Himantura gerrardi, Tilapia, C. nigrodigitatus against several infectious microbes. Ebran et al. (1999) reported that the epidermal mucus of $O$. mykiss exhibited MIC at $50 \mu \mathrm{g} \mathrm{ml}^{-1}$ against $S$. aureus, Tinca tinca at $60 \mu \mathrm{g} \mathrm{ml}^{-1}$ against A. hydrophila and C. carpio at $50 \mu \mathrm{g} \mathrm{ml}$ against $S$. aureus, supporting the present results. Also Hellio et al. (2002) observed the MICs value of many fish species against different microbial strains in the range of $25-48 \mu \mathrm{g} \mathrm{ml}^{-1}$. Our results are also similar to these studies.

Contradictory to our findings, Cole et al. (1997) reported that the mucus extracts of winter flounder and moses fish in the range of 40-200 $\mathrm{mg} \mathrm{l}^{-1}$ was necessary to inhibit the growth of $P$. aeruginosa, E. coli, and A. hydrophila. Lemaitre et al. (1996) reported that glycosylated proteins of MW $27 \mathrm{kDa}$ and $31 \mathrm{kDa}$ isolated from $C$. carpio strongly inhibits the growth of all tested pathogens at approximately $5 \mu \mathrm{g} \mathrm{ml}{ }^{-1}$. Similarly, Ebran et al. (2000) noticed that three proteins $(45 \mathrm{kDa}, 49 \mathrm{kDa}$, and $65 \mathrm{kDa}$ ) from hydrophobic supernatant of skin mucus of eel, tench and trout showed MICs values ranging from 1 to $5 \mu \mathrm{g} \mathrm{ml}{ }^{-1}$. However, same fish or different fishes exhibited different MIC against different or same bacterial strains. Different age, habits and habitats of different fishes could be the reason behind these variations. Thus, more studies are required to unhide the antibacterial role of skin mucus of these economically important exogenous carp species. 


\section{Conclusion}

In the present study, an increase in mucus secretion after exposure to bacterial challenges indicates its involvement in protection against pathogenic attacks. Higher mucus secretion could be an indicator of increased stress level in fishes. Both crude and aqueous mucus extracts of healthy and challenged fishes showed broad spectrum of bactericidal activity against tested human and fish pathogenic bacteria. Therefore, fish skin mucus might contain antibacterial compounds which can be utilized as an alternative of antibiotics which perhaps could be employed in aquaculture and also for humans. Being a natural product, therefore, it could help in reducing the problems of antibiotic resistance and thus could prove to be a cost effective product.

Acknowledgements We would like to thank Chairman, Department of Zoology, Kurukshetra University, Kurukshetra and Administration, Kurukshetra University, Kurukshetra for providing the necessary facilities. Authors are also grateful to Dr. Aparna, Associate Professor of English, CCS Haryana Agricultural University, Hisar for reading the manuscript from linguistic point of view.

Open Access This article is distributed under the terms of the Creative Commons Attribution 4.0 International License (http:// creativecommons.org/licenses/by/4.0/), which permits unrestricted use, distribution, and reproduction in any medium, provided you give appropriate credit to the original author(s) and the source, provide a link to the Creative Commons license, and indicate if changes were made.

\section{References}

Al-Arifa N, Batool A, Hanif A (2013) Effects of alkaline pH on protein and fatty acid profiles of epidermal mucus from Labeo rohita. J Anim Plant Sci 23(4):1045-1051

Alvarez-Pellitero P (2008) Fish immunity and parasite infections: from innate immunity to immune prophylactic prospects. Vet Immunol Immunopathol 126(3-4):171-198. https://doi.org/10.1016/j.vetimm.2008.07.013

Anbuchezhian R, Gobinath C, Ravichandran S (2011) Antimicrobial peptide from the epidermal mucus of some estuarine cat fishes. WASJ 12(3):256-260

Arulvasu C, Selvamathi S, Babu G, Dhanasekaran G (2012) Effect of crude and partially purified epidermal mucus proteins of marine catfish Tachysurus dussumieri on human cancer cell line. J Acad Indus Res 1(4):164-169

Austin B, Stuckey LF, Robertson PAW, Effendi I, Griffith DRW (1995) A probiotic strain of Vibrio alginolyticus effective in reducing diseases caused by Aeromonas salmonicida, Vibrio anguillarum and Vibrio ordalii. J Fish Dis 18:93-96. https://doi. org/10.1111/j.1365-2761.1988.tb00550

Balasubramanian S, Baby Rani P, Arul Prakash A, Prakash M (2012) Antimicrobial properties of skin mucus from four freshwater cultivable Fishes (Catla catla, Hypophthalmichthys molitrix, Labeo rohita and Ctenopharyngodon idella). Afr J Microbiol Res 6(24):5110-5120. https://doi.org/10.5897/AJMR11.532

Barbosa HR, Rodrigues MFA, Campos CC, Chaves ME, Nunes I, Juliano Y, Novo NF (1995) Counting of viable cluster-forming and non cluster-forming bacteria: a comparison between the drop and the spread methods. J Microbiolol Methods 22:39-50. https://doi.org/10.1016/0167-7012

Bragadeeswaran S, Thangaraj S (2011) Hemolytic and Antibacterial studies on skin mucus of Eel fish Anguilla anguilla Linnaues. Asian J Biol Sci 4(3):272-276. https://doi.org/10.3923/ajbs.2011.272.276

Chong K, Ying TS, Foou J, Jin LT, Chong A (2005) Characterization of proteins in epidermal mucus of Discus fish (Symphosodon spp.) during parental phase. Aquaculture 249:469-476. https://doi.org/10.1016/j.aquaculture.2005.02.045

Cole AM, Weis P, Diamond G (1997) Isolation and characterization of pleurocidin, an antimicrobial peptide in the skin secretions of winter flounder. J Biochem 272:12008-12013. https://doi.org/10.1074/jbc.272.18.12008

Cooper MA, Shlaes D (2011) Fix the antibiotics pipeline. Nature 472(7341):32. https://doi.org/10.1038/42032a

Dash SK, Samal J, Thatoi HN (2018) Epidermal mucus, a major determinant in fish health: a review. Iran J Vet Res 19(2):72-81. https://doi.org/10.22099/ijvr.2018.4849

Duncan DB (1955) Multiple ranges and multiple F-tests. Biometrics 11:1-42. https://doi.org/10.2307/3001478

Ebran N, Julien S, Orange N, Saglio P, Lemaitre C, Molle G (1999) Pore-forming properties and antibacterial activity of proteins extracted from the epidermal mucus of fish. Comp Biochem Physiol B 122:181-189. https://doi.org/10.1016/S1095-6433

Ebran N, Julien S, Orange N, Molle G (2000) Isolation and characterization of novels glycoproteins from fish epidermal mucus: correlation between their pore forming properties and their antibacterial activities. Biochemica et Biophysica Acta 1467:271-280. https://doi.org/10.1016/S0005-2736

Eder FA, Kennedy JM, Beth AD, Notari PE, Seate R, Bachousin L, Mair DG, Swebb JS, Wagner JS, Doddy R, Banjamin RJ (2009) Limiting and detecting bacterial contamination of apheresis platelets: inlet line diversion and increased culture volume improve component safety. Tranfusion 49(8):1554-1563. https://doi.org/10.1111/j.1537-2995.2009

Ellis AE (2001) The immunology of teleosts. In: Roberts RJ (ed) Fish pathology, 3rd edn. Elsevier, New York, pp 133-150

Fuochi V, Volti GL, Camiolo G, Tiralongo F, Giallongo C, Distefano A, Petronio-Petronio G, Barbagallo I, Viola M, Furneri PM et al (2017) Antimicrobial and anti-proliferative effects of skin mucus derived from Dasyatis pastinaca (Linnaeus 1758). Mar Drugs 15(11):342. https://doi.org/10.3390/md1110342 
Guardiola FA, Cuesta A, Abellán E, Meseguer J, Esteban MA (2014) Comparative analysis of the humoral immunity of skin mucus from several marine teleost fish. Fish Shell Fish Immunol 40:24-31. https://doi.org/10.1016/j.fsi.2014.06.018

Hedmon O (2018) Fish mucus: a neglected reservoir for antimicrobial peptides. AJPRD 6(4):06-11

Hellio C, Pons AM, Beaupoil C, Bourgougnon N, Gal YL (2002) Antibacterial, antifungal and cytotoxic activities of extracts from fish epidermis and epidermal mucus. Int J Antimicrob Agents 20(3):214-219. https://doi.org/10.1016/S0924-8579

Holm H, Santi N, Kjoglum S, Perisic N, Skugor S, Evensena O (2015) Difference in skin immune responses to infection with salmon louse (Lepeophtheirus salmonis) in Atlantic salmon (Salmo salar L.) of families selected for resistance and susceptibility. Fish Shell fish Immunol 42(2):384-394. https://doi.org/10.1016/j.fsi.2014.10.038

Jones SRM (2001) The occurrence and mechanisms of innate immunity against parasites in fish. Dev Comp Immunol 25(8-9):841-852. https://doi.org/10.1016/S0145-305X

Jorgensen J, Turnidge J (2015) Susceptibility Test Methods: Dilution and Disk Diffusion Methods. In: Jorgensen J, Pfaller M, Carroll K, Funke G, Landry M, Richter S, Warnock D (eds) Manual of clinical microbiology, 11th edn. ASM Press, Washington, DC, pp 1253-1273

Jung TS, Castillo CSD, Javaregowda PK, Dalvi RS, Nho SW, Bin PS (2012) Seasonal variation and comparative analysis of nonspecific humoral immune substances in the skin mucus of olive flounder (Paralichthys olivaceus). Dev Comp Immunol 38(2):295-301. https://doi.org/10.1016/j.dci.2012.06.005

Kumari U, Nigam AK, Mitial S, Mitial AK (2011) Antibacterial properties of the skin mucus of the freshwater fishes, Rita rita and Channa punctatus. Eur Rev Med Pharmacol Sci 15(7):781-786

Kuppulakshmi C, Prakash M, Gunasekaran G, Manimegalai G, Sarojini S (2008) Antibacterial properties of fish mucus from Channa punctatus and Cirrhinus mrigala. Eur Rev Med Pharmacol Sci 12:149-153

Lemaitre C, Orange N, Saglio P, Saint N, Gagnon J, Molle G (1996) Characterization and ion channel activities of novel antimicrobial proteins from the skin mucosa of carp (Cyprinus carpio). Eur J Bioche 240:143-149. https://doi.org/10.1111/j. 1432-1033.1996

Lirio JAC, Deleon JAA, Villafuerte AG (2018) Antimicrobial activity of epidermal mucus from top aquaculture fish species against medically-important pathogens. Walailak J Sci Technol 16(5):329-340. https://doi.org/10.13140/RG.2.2.33812.1425

Lowry OH, Rosenbrough NJ, Farr AL, Randall RJ (1951) protein measurements with the folin phenol reagent. J Biol Chem 193:265-275 (PMID:14907713)

Manivasagan P, Annamali N, Ashok KS, Sampathkumar P (2009) Studies on the proteinous gel secretion from the Skin of the catfish, Arius maculatus (Thunberg, 1792). Afr J Biotechnol 8(24):7125-7129

Nagashima Y, Sendo A, Shimakura K, Kobayashi T, Kimura T, Fujii T (2001) Antibacterial factors in skin mucus of rabbit fishes. J Fish Biol 58:1761-1765. https://doi.org/10.1111/j.1095-8649.2001.tb02331

Nagashima Y, Kikuchi N, Shimakura K, Shiomi K (2003) Purification and characterization of an antibacterial protein in the skin secretion of rockfish Sebastes schlegelii. Comp Biochem Physiol C Toxicol Pharmacol 136:63-71. https://doi.org/10.1016/ S1532-0456

Nigam A, Kumari U, Mittal S, Mittal A (2012) Comparative analysis of innate immune parameters of the skin mucous secretions from certain freshwater teleosts, inhabiting different ecological niches. Fish Physiol Biochem 38:1245-1256. https://doi.org/ $10.1007 / \mathrm{s} 10695-012-9613-5$

Nurtamin T, Nurman RY, Hafizah I (2016) Antibacterial activity of eel mucus against Salmonella typhi. Indones Biomed J 8(3):179-182. https://doi.org/10.18585/inabj.v8i3.231

Pearson J, Brownlee IA (2005) A surface and function of mucosal surface. In: Natro JP (ed) Colonization of mucosal surface. ASM Press, Washington D.C.

Prakash M, Loganathan K, Arul PA, Senthilraja P, Gunaesekaran G (2013) Studies on the antimicrobial and hemolytic activity of the mucus of freshwater snakehead fish Channa striatus. IJBPAS 2(4):866-878

Raj VS, Fournier G, Rakus K, Ronsmans M, Ouyang P, Michel O, Delforges C, Costes B, Farnir F, Leroy B, Wattiez R, Melard C, Mast J, Lieffrig F, Vanderplasschen A (2011) Skin mucus of Cyprinus carpio inhibits cyprinid herpes virus 3 binding to epidermal cells. Vet Res 42(1):92. https://doi.org/10.1186/1297-9716-42-92

Rao V, Marimuthu K, Kupusamy T, Rathinam X, Arasu MV, Al-Dhabi NA (2015) Defense properties in the epidermal mucus of different freshwater fish species. AACL Bioflux 8(2):184-194

Reverter M, Tapissier-Bontemps N, Lecchini D, Banaigs B, Sasal P (2018) Biological and ecological roles of external fish mucus: a review. Fishes 3(4):41. https://doi.org/10.3390/fishes/3040041

Subramanian S, Mackinnon S, Ross NW (2007) A comparative study on innate immune parameters in the epidermal mucus of various fish species. Comp Biochem Physiol B Biochem Mol Biol 148(3):256-263. https://doi.org/10.1016/j.cbpb.2007.06. 003

Subramanian S, Ross NW, Mackinnon SL (2008) Comparison of antimicrobial activity in the epidermal mucus extracts of fish. Comp Biochem Physiol B Biochem Mol Biol 150(1):85-92. https://doi.org/10.1016/j.cbpb.2008.01.011

Subramanian S, Ross NW, Mackinnon SL (2009) Myxinidin, a novel antimicrobial peptide from the epidermal mucus of hagfish, Myxine glutinosa (L.). J Mar Biotechnol 11:748-757. https://doi.org/10.1007/s10126-009-9189-y

Valgas C, De-Souza SM, Smania EFA, Jr Smania (2007) Screening methods to determine antibacterial activity of natural products. Braz J Microbiol 38(2):369-380. https://doi.org/10.1590/S1517-83822007000200034

Vennila R, Kumar RK, Kanchana S, Arumugam M, Vijayalakshmi S, Balasubramaniam T (2011) Preliminary investigation on the antimicrobial and proteolytic property of the epidermal mucus secretion of marine stingrays. Asian Pac J Trop Biomed $1: 239-243$

Wei OY, Xavier R, Marimuthu K (2010) Screening of antibacterial activity of mucus extract of snakehead fish, Channa striatus (Bloch). Eur Rev Med Pharmacol Sci 14:675-681 
Wiegand I, Hilpert K, Hancock Robert EW (2008) Agar and broth dilution methods to determine the minimal inhibitory concentration (MIC) of antimicrobial substances. Nat Protoc 3:163. https://doi.org/10.1038/nprot.2007.521

\section{Publisher's Note}

Springer Nature remains neutral with regard to jurisdictional claims in published maps and institutional affiliations. 